\title{
EFFECT OF GALLAMINE ON CHOLINERGIC RECEPTORS*
}

\author{
Flora J. Rathbun, m.Sc., and John T. Hamilton, Ph.D. $\dagger$
}

EVER SINCE the introduction of gallamine triethiodide (Flaxedil(1)) into clinical anaesthesia in 1948 by Huguenard and Boué, ${ }^{1}$ there have been numerous reports of sinus tachycardia as a side effect. ${ }^{2-4}$ Gallamine was found to have a vagolytic action localized in the heart, and for a long time it was presumed that this was the cause of the tachycardia. ${ }^{5}$ Recently, however, Brown and Crout ${ }^{6,7}$ and Smith and Whitcher ${ }^{2}$ have demonstrated that gallamine may cause positive inotropic and chronotropic activity in both animals and man due to the release of catecholamines from cardiac sympathetic nerves. It therefore seemed appropriate to have a closer look at the action of gallamine on the heart to see if we could demonstrate a true antiacetylcholine activity and moreover to determine if this was a competitive or non-competitive receptor interaction.

As a potentiation or activation of the sympathetic nervous system would result in an antagonism similar to antimuscarinic action, it was decided to conduct these experiments in the presence of doses of propranolol hydrochloride sufficient to block cardiac sympathetic receptors. In an attempt to measure the antiacetylcholine activity of gallamine in spontaneously beating, yet sympathetically blocked hearts, in vivo preparations were chosen.

To avoid the use of anaesthetics and the complications of either reflex or central actions of any of the drugs employed, pithed rats and spinally transected cats with their brains destroyed were employed.

\section{Materlals and Methods}

Male Sprague-Dawley rats, mean weight $340 \pm 7 \mathrm{gm}$, were anaesthetized with diethyl ether and a tracheal cannula inserted for controlled respiration by means of a Palmer Ideal Respiration Pump set at a rate of 67 strokes per minute and at a suitable stroke volume. The rats were then pithed, as described by Shipley and Tilden, ${ }^{8}$ by inserting a metal rod through the orbit and down the vertebral column. Blood pressure and heart rate were recorded by cannulating the right carotid artery using Statham transducers and a Grass $\mathrm{p} 7$ polygraph. All drugs were given intravenously via a cannula in the right femoral vein in a volume of $0.1 \mathrm{ml} 0.9$ per cent sodium chloride. Experiments were performed on a total of 29 rats given either 8,16 , or $64 \mathrm{mg} / \mathrm{kg}$ of gallamine; 10 similar rats, chosen at random, served as saline-treated controls. Half of the rats were pretreated with

"Supported in part by a grant-in-aid from the Ontario Heart Foundation of Canada, grant 3-15, and in part from the Medical Research Council of Canada, grant MA 1216.

TMiss Rathbun is a M.SC.M.D. candidate in the Department of Pharmacology, University of Western Ontario, and holder of the Ruth Knox Herman Fellowship for research in the general field of cardiovascular disease, 1968-69. Dr. Hamilton is Associate Professor of Pharmacology, University of Western Ontario, London, Ontario.

Can. Anaes. Soc. J., vol. 17, no. 6, November 1970 
propranolol ( $1.5 \mathrm{mg}$ per rat); the other rats received no propranolol. As propranolol did not significantly change the dose-response curves to acetylcholine iodide, the propranolol and non-propanolol groups were treated as one.

For comparison, dose-response curves were measured in 15 rats after 0.125 , 0.250 , or $1.00 \mathrm{mg} / \mathrm{kg}$ of atropine sulphate; seven rats served as controls. No propranolol was given this time, as in the previous study it did not significantly affect the dose-response curves.

Dose-response curves were repeated following pretreatment with $4 \mathrm{mg} / \mathrm{kg}$ hexamethonium and $16 \mathrm{mg} / \mathrm{kg}$ gallamine (five rats) or $0.250 \mathrm{mg} / \mathrm{kg}$ atropine (five rats). Four similar rats given hexamethonium and saline served as controls. All rats in this series were pretreated, as a precaution, with propranolol.

Healthy cats, mean weight $2.50 \mathrm{~kg}$, were likewise anaesthetized with diethyl ether and a tracheal cannula was inserted for subsequent controlled respiration by means of a Harvard Respiration Pump at 18 strokes per minute and a stroke volume of $70 \mathrm{cc}$. The cats maintained under ether were prepared by the method of Burn ${ }^{9}$ by cutting the spinal cord at the level of the second cervical vertebra and destroying the brain by pushing a stout probe through the foramen magnum (hereafter called a spinal preparation). Blood pressure was recorded from the right carotid artery with a Statham transducer and a Grass $\mathrm{P} 7$ polygraph and all drugs were administered via a cannula in the right femoral vein. Doseresponse curves for the negative chronotropic response of intravenously administered acetylcholine iodide were obtained in 12 cats after 1,4 , or $16 \mathrm{mg} / \mathrm{kg}$ of gallamine, each cat serving as its own control. Five similar experiments were performed on cats selected randomly and treated with $2 \mathrm{mg} / \mathrm{kg}$ of atropine. All animals were also pretreated with $1 \mathrm{mg} / \mathrm{kg}$ propranolol. Dose-response curves were re-established following pretreatment with an initial dose of $4 \mathrm{mg} / \mathrm{kg}$ hexamethonium, followed by $2 \mathrm{mg} / \mathrm{kg}$ hexamethonium every 30 minutes in seven cats which received $16 \mathrm{mg} / \mathrm{kg}$ gallamine, and in five cats which received $2 \mathrm{mg} / \mathrm{kg}$ atropine. Three similar cats served as controls, only they received saline instead of gallamine or atropine.

The dose of propranolol chosen was sufficient to reduce the tachycardia induced by $4 \mu \mathrm{g} / \mathrm{kg}$ of isoproterenol, administered intravenously, to 10 per cent or less. One-half of this amount of isoproterenol in the absence of propranolol consistently caused a $40-50$ per cent increase in the heart rate. This was equivalent, in retrospect, to about a four-fold shift of the dose-response curve to isoproterenol.

Due to the brevity of the response to acetylcholine on both species the dose response curves could be rapidly determined, at least in duplicate, in within 30 to 40 minutes. Always 5 to 10 minutes were allowed for equilibration following the appropriate pretreatment therapy.

All results were analysed by the method of Litchfield and Wilcoxon. ${ }^{10}$ Affinity constants ${ }^{11}$ for gallamine and atropine were then estimated. As it was impossible to know the actual concentration of antagonist at the receptor, approximations were made by assuming that the quaternary ammonium compound, gallamine, was restricted to the extracellular fluid space, whereas atropine was distributed throughout the total body water. Thus "apparent" rather than "true" affinity 
constants were obtained. In the rat the extracellular space is approximately 30 per cent of the total body weight, ${ }^{12,18}$ whereas the total body water averages $660 \mathrm{ml} / \mathrm{kg}$ body weight. ${ }^{14}$ In the cat the extracellular fluid space is approximately $300 \mathrm{ml} / \mathrm{kg}^{15}$ and the total body water is $677 \mathrm{ml} / \mathrm{kg}$ body weight. ${ }^{16-18}$

In vitro experiments were also performed on the guinea pig ileum ${ }^{19}$ and the guinea pig ileum longitudinal muscle strip ${ }^{20,21}$ in order to determine the affinity of gallamine for cholinergic gut receptors. Carbachol was used as the stimulant throughout, and all solutions contained $1 \times 10^{-4} \mathrm{M}$ hexamethonium. The muscarinic drug carbachol was used on this preparation as it is believed that the affinity constant of an antagonist is independent, whether acetylcholine or carbachol is employed as the agonist.

\section{Tests for competition}

1. Classical Lineweaver-Burk or double-reciprocal plots as described by Webb $^{22}$ and Dowd and Riggs ${ }^{23}$ were drawn for both atropine and gallamine in the rat and cat.

2. A test recently described in detail by Abramson, Barlow, Mustafa, and Stephenson ${ }^{24}$ was carried out in both species. These authors have employed a method previously applied by Ariens, Simonis, and Van Rossum. ${ }^{25}$ Paton and Rang ${ }^{26}$ have pointed out that the dose ratio $\mathrm{DR}_{1+2}$ obtained when two competitive antagonists are given together is equal to $\mathrm{DR}_{1}+\mathrm{DR}_{2}-1$, where $\mathrm{DR}_{1}$ and $\mathrm{DR}_{2}$ are the dose ratios obtained with these concentrations of antagonists acting separately. However, if either antagonist is acting noncompetitively, then the dose ratio of the two acting together would be $\mathrm{DR}_{1} \times \mathrm{DR}_{2}$. Thus if both antagonists are competitive and can compete with each other as well as with the agonist, then the experimentally determined value of $\mathrm{DR}_{1+2} / \mathrm{DR}_{1}$ will be equal to the theoretically calculated value of $\left[1+\left(\mathrm{DR}_{2}-1\right) / \mathrm{DR}_{1}\right]$, a value usually between 1 and 2. However, if the drug-receptor interaction of either antagonist is non-competitive, then the experimentally determined value of $\mathrm{DR}_{1+2} / \mathrm{DR}_{1}$ will be equal to the theoretically calculated value of $\mathrm{DR}_{1} \times \mathrm{DR}_{2} / \mathrm{DR}_{1}$, i.e. $\mathrm{DR}_{2}$, the dose ratio found with the non-competitive drug alone as though no other drug was present.

\section{Results}

Table I and Figure la show that gallamine, in doses of 8,16 , or $64 \mathrm{mg} / \mathrm{kg}$, caused a parallel shift of the acetylcholine log-dose-response curves to the right, as determined on 29 pithed rat preparations. All dose-response curves differed significantly $(p<0.05)$ from the control curve determined on ten rats and from each other except in the case of the 8 and $16 \mathrm{mg} / \mathrm{kg}$ gallamine curves. Table II and Figure $1 b$ show a similar series of curves when $0.125,0.250$, or $1.00 \mathrm{mg} / \mathrm{kg}$ of atropine was administered to 22 similar rats. Analogous results were obtained in 12 spinal cat preparations pretreated with 1,4 , and $/$ or $16 \mathrm{mg} / \mathrm{kg}$ gallamine (Table III, Figure $1 c$ ) and in five spinal cats given $2 \mathrm{mg} / \mathrm{kg}$ atropine (Figure $1 \mathrm{~d}$ ).

From this data the apparent affinity constants for gallamine and atropine in the pithed rat and spinal cat preparations were calculated (Table IV). As the apparent affinity constants, determined at the different dose levels of antagonist, were 


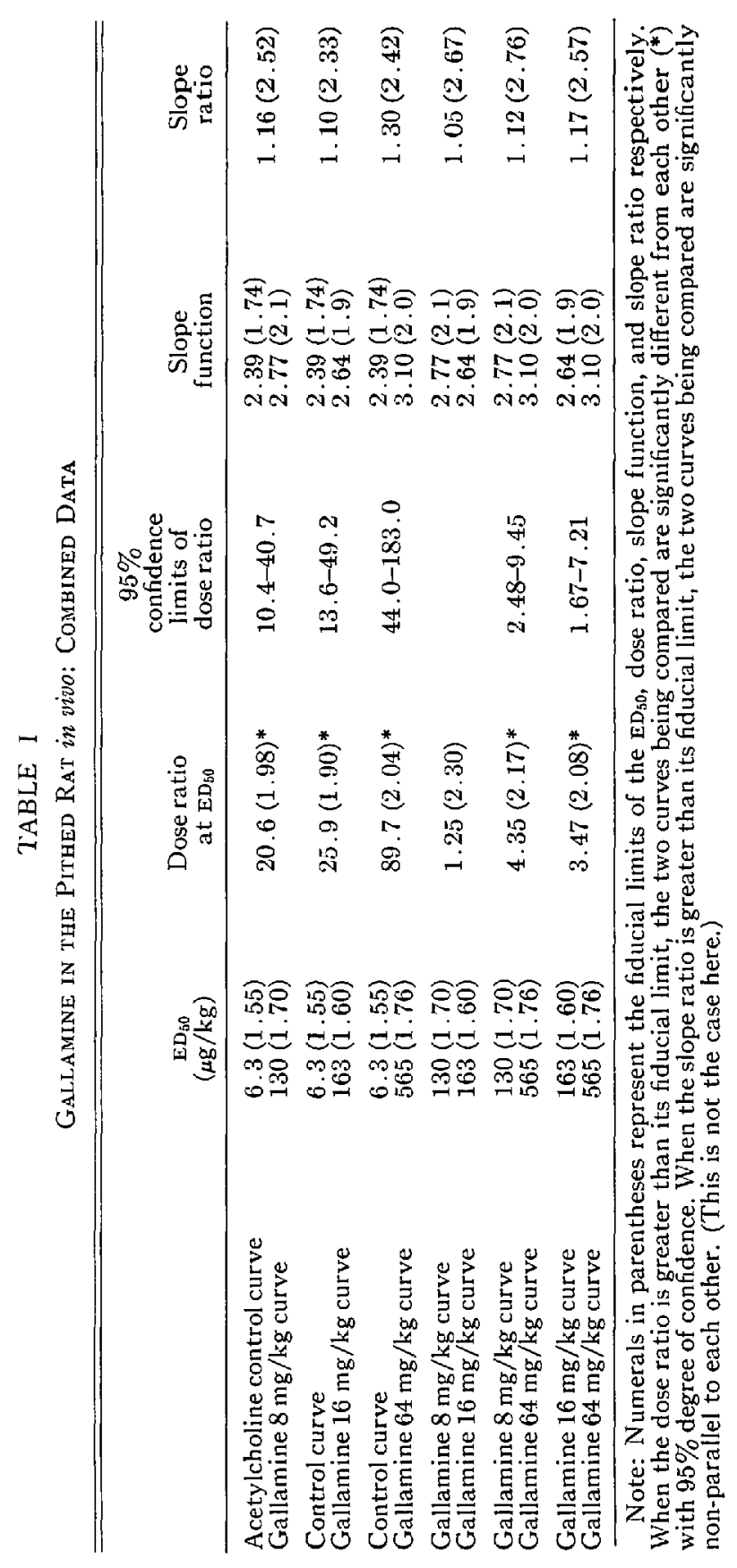



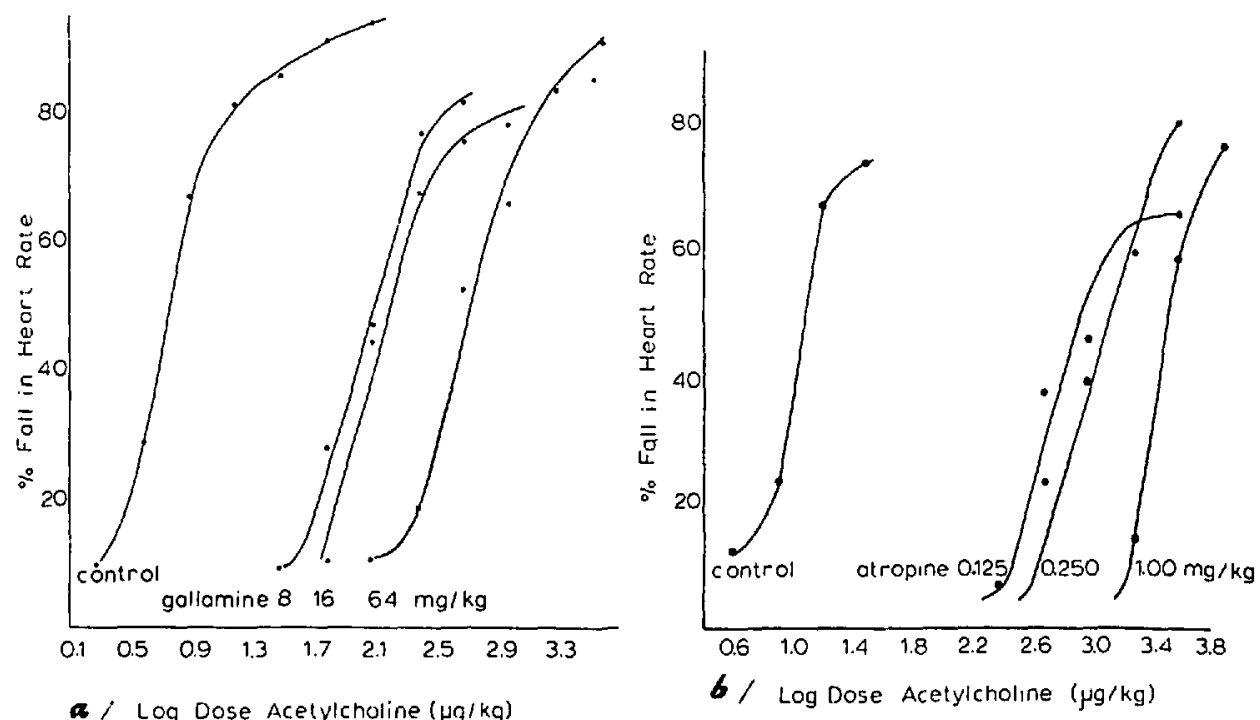

a, $\log$ Dose Acetylcholine $(\mu g / \mathrm{kg})$
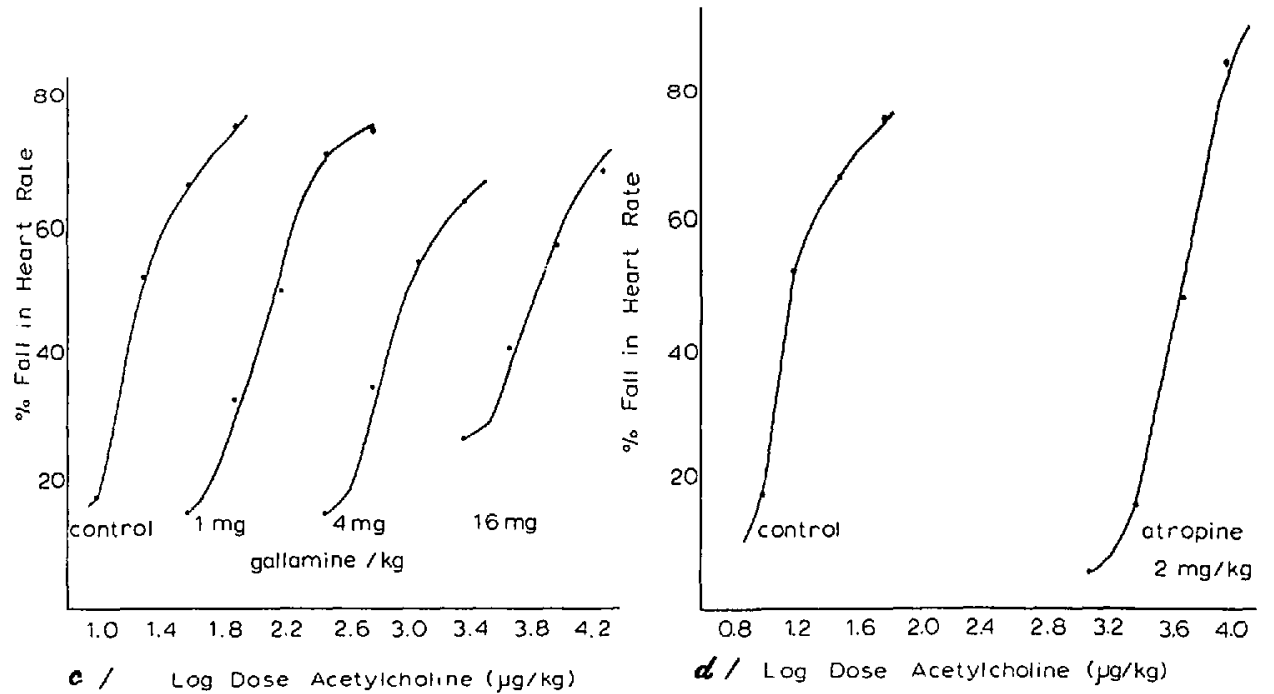

Figure 1. The effect of one or more doses of antagonist (either atropine or gallamine) on the negative chronotropic action of acetylcholine in the pithed rat ( $a$ and $b$ ) and spinal cat $(c$ and $d)$. Graph $a$ shows combined propranolol-non-propranolol data. No rats in $b$ received propranolol. All cats ( $c$ and $d$ ) received propranolol.

not significantly different, as indicated by the fiducial limits, average values were calculated for each antagonist in both species. A marked species difference was noted when the ratio of the apparent affinity constants for atropine-gallamine was examined. This ratio was 205 on the rat as compared to only 9 on the cat.

When hexamethonium was administered to pithed rats there was a parallel and significant $(p<0.05)$ shift to the right of the control curve as well as the curve obtained with $16 \mathrm{mg} / \mathrm{kg}$ of gallamine present (Figure $2 a$ ). There was a non-significant shift to the right with $0.250 \mathrm{mg} / \mathrm{kg}$ of atropine present. The apparent affinity constants were, however, not significantly altered $(p>0.05)$. 


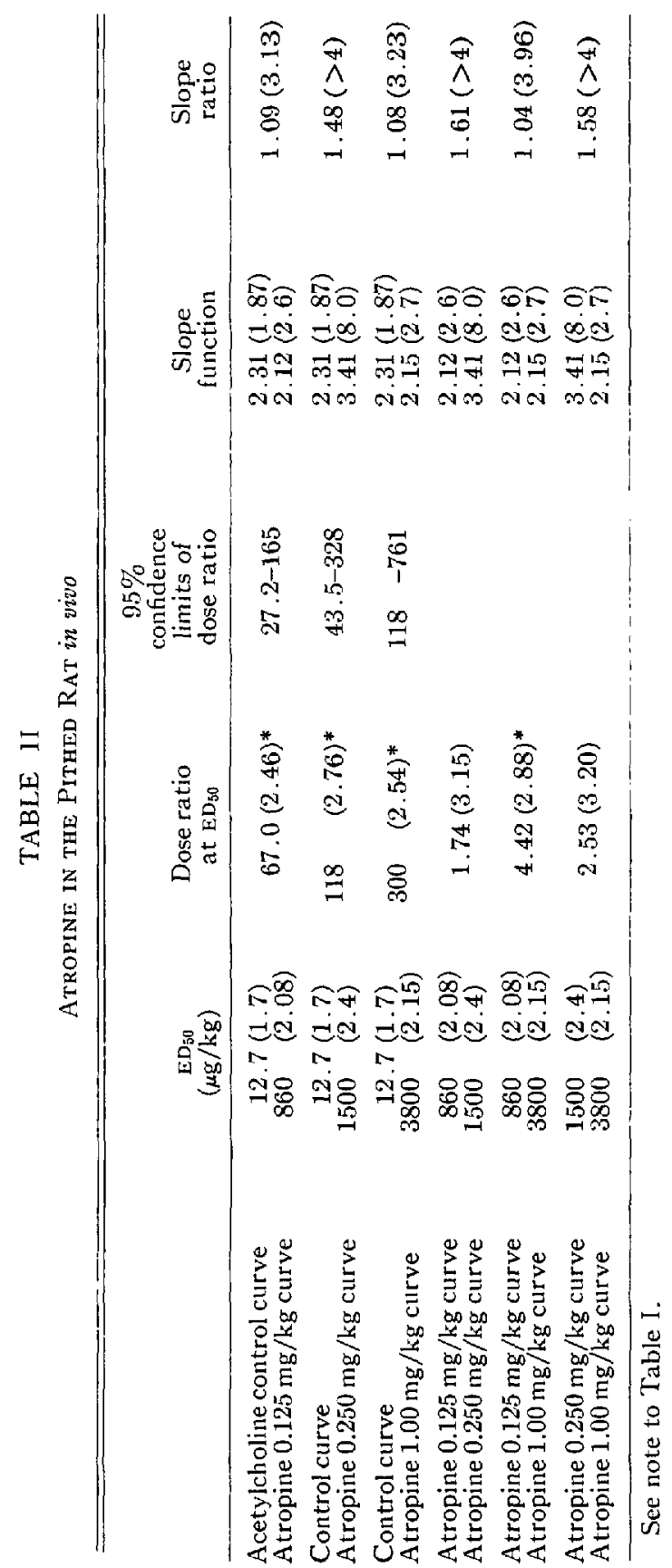




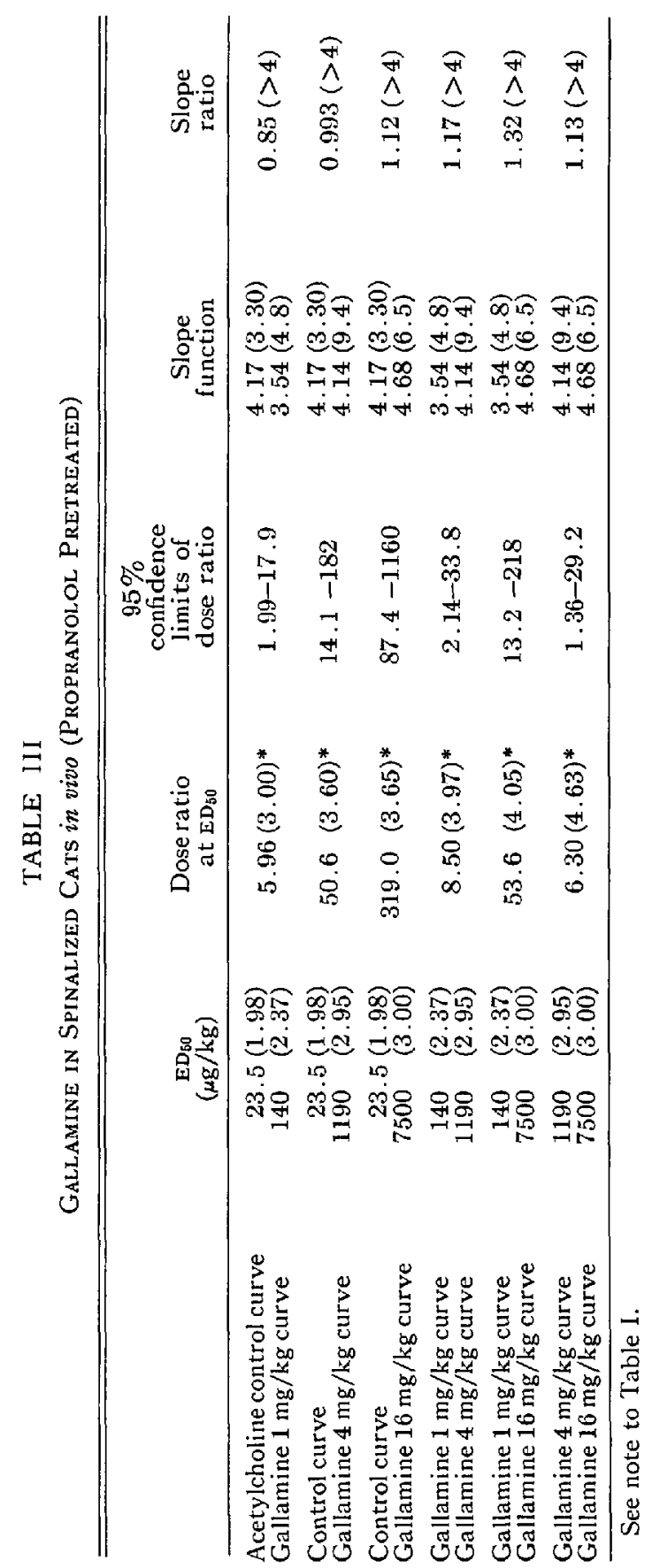




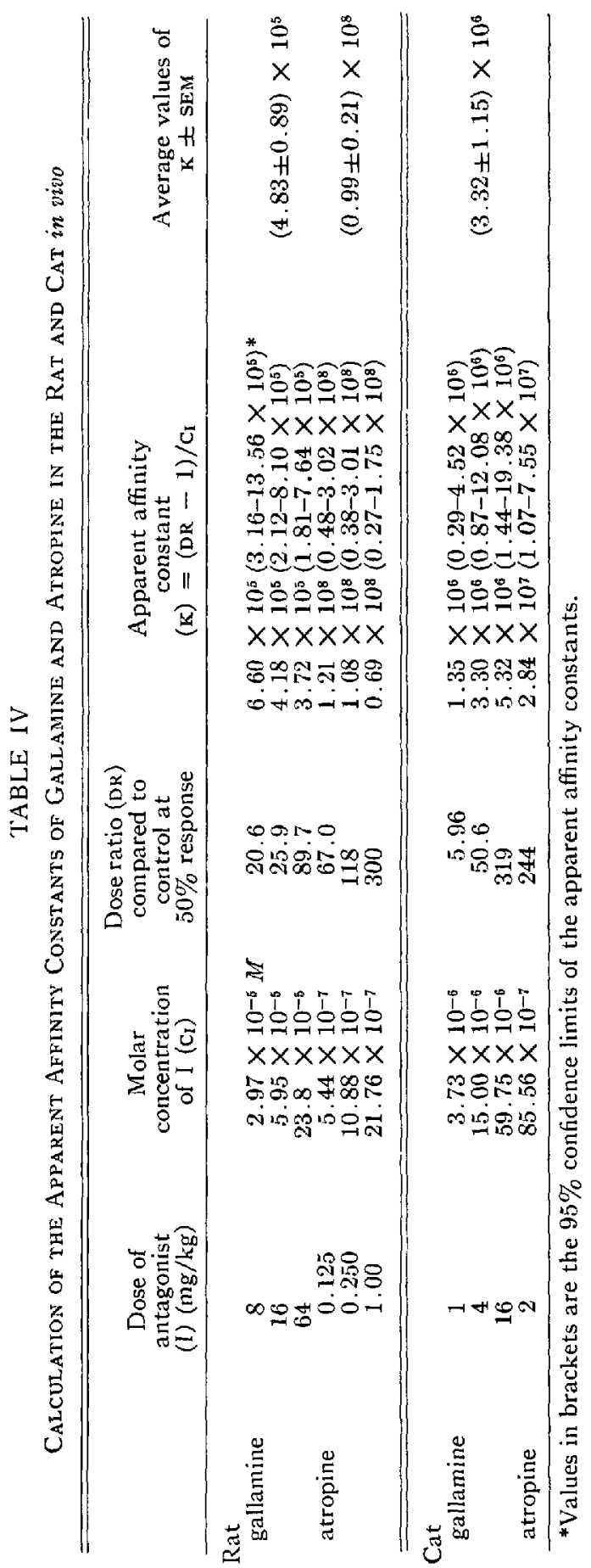




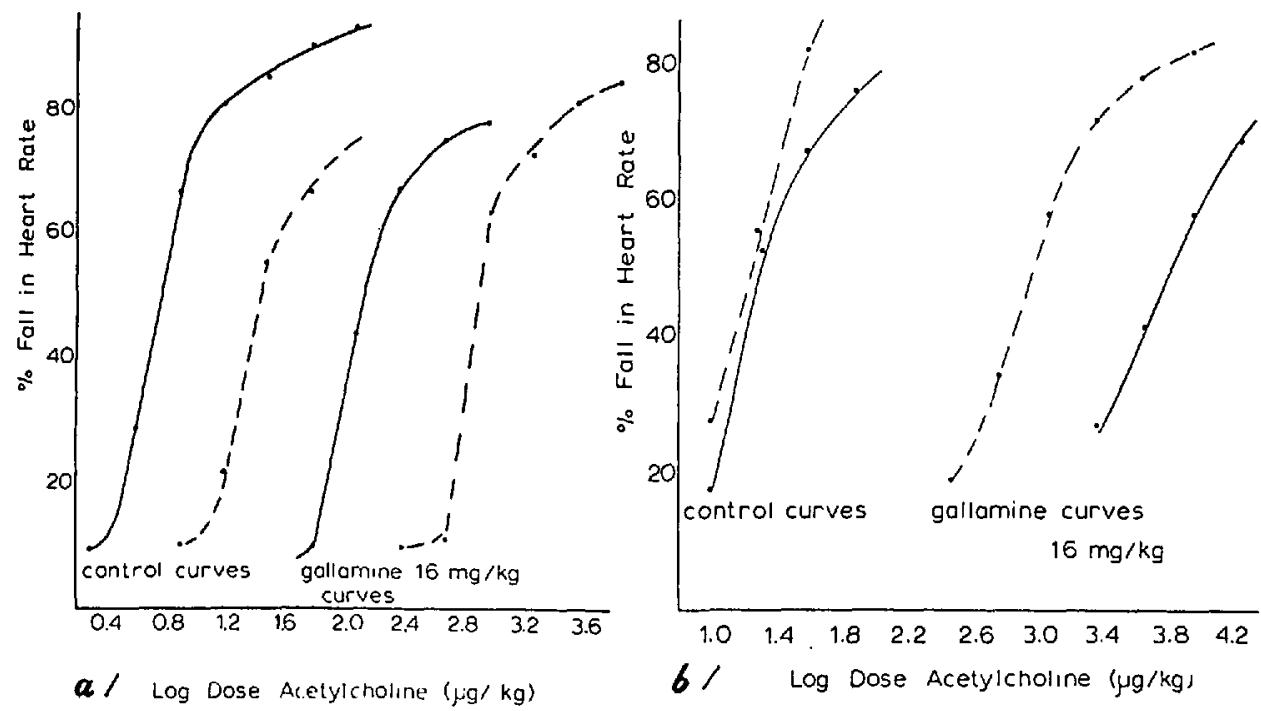

Figure 2. The effect of hexamethonium on the negative chronotropic action of acetylcholine with and without gallamine in pithed rats $(a)$ and spinal cats $(b)$.

In the spinal cat, following the administration of hexamethonium, neither the control curve nor the curve obtained in the presence of $2 \mathrm{mg} / \mathrm{kg}$ atropine was significantly altered $(p>0.05)$; however, the curve obtained with $16 \mathrm{mg} / \mathrm{kg}$ of gallamine on the cat was significantly shifted to the left, decreasing the apparent affinity constant from 5.32 to $1.02 \times 10^{6}$ (Figure $2 b$ ).

The average affinity constants obtained for gallamine and atropine in the guinea pig ileum and guinea pig ileum longitudinal muscle strip in vitro are shown in Table V. Gallamine had a very low affinity for gut receptors as compared to

TABLE $V$

Calculation of the Affinity Constants of Gallamine and Atropine on the Cholinergic Gut Receptors of The Guinea PIg in vitro

\begin{tabular}{|c|c|c|}
\hline $\begin{array}{l}\text { Antagonist } \\
\text { concentration }\end{array}$ & $\begin{array}{l}\text { Average dose } \\
\text { ratio } \pm \text { SEM }\end{array}$ & $\begin{array}{l}\text { Average affinity } \\
\text { constants } \pm \text { SEM }\end{array}$ \\
\hline $\begin{array}{l}\text { Guinea pig ileum } \\
\qquad 1 \times 10^{-4} M \text { gallamine }\end{array}$ & $2.91 \pm 0.19(2)^{*}$ & $(1.91 \pm 0.19) \times 10^{4}$ \\
\hline $\begin{array}{l}\text { Guinea pig ileum longitud } \\
1 \times 10^{-4} M \text { gallamine } \\
2 \times 10^{-7} M \text { atropine }\end{array}$ & $\begin{array}{l}\text { cle strip } \\
1.59 \pm 0.29 \text { (3) } \\
245 \pm 11\end{array}$ & $\begin{array}{l}(0.58 \pm 0.29) \times 10^{4} \\
(1.23 \pm 0.07) \times 10^{9}\end{array}$ \\
\hline
\end{tabular}

*Values in brackets represent the number of assays.

atropine, the ratio of affinity constants being 1:212,000. Gallamine was 1/1000 as active on gut as on cat heart receptors and 1/100 on gut as on rat heart receptors. In contrast, atropine obviously had a greater affinity for gut than for cardiac receptors (compare Tables IV and V).

The double-reciprocal plots for both gallamine and atropine in the cat and the rat are shown in Figure 3. The lines varied in slope and $x$ intercept, but had the same $y$ intercept. 


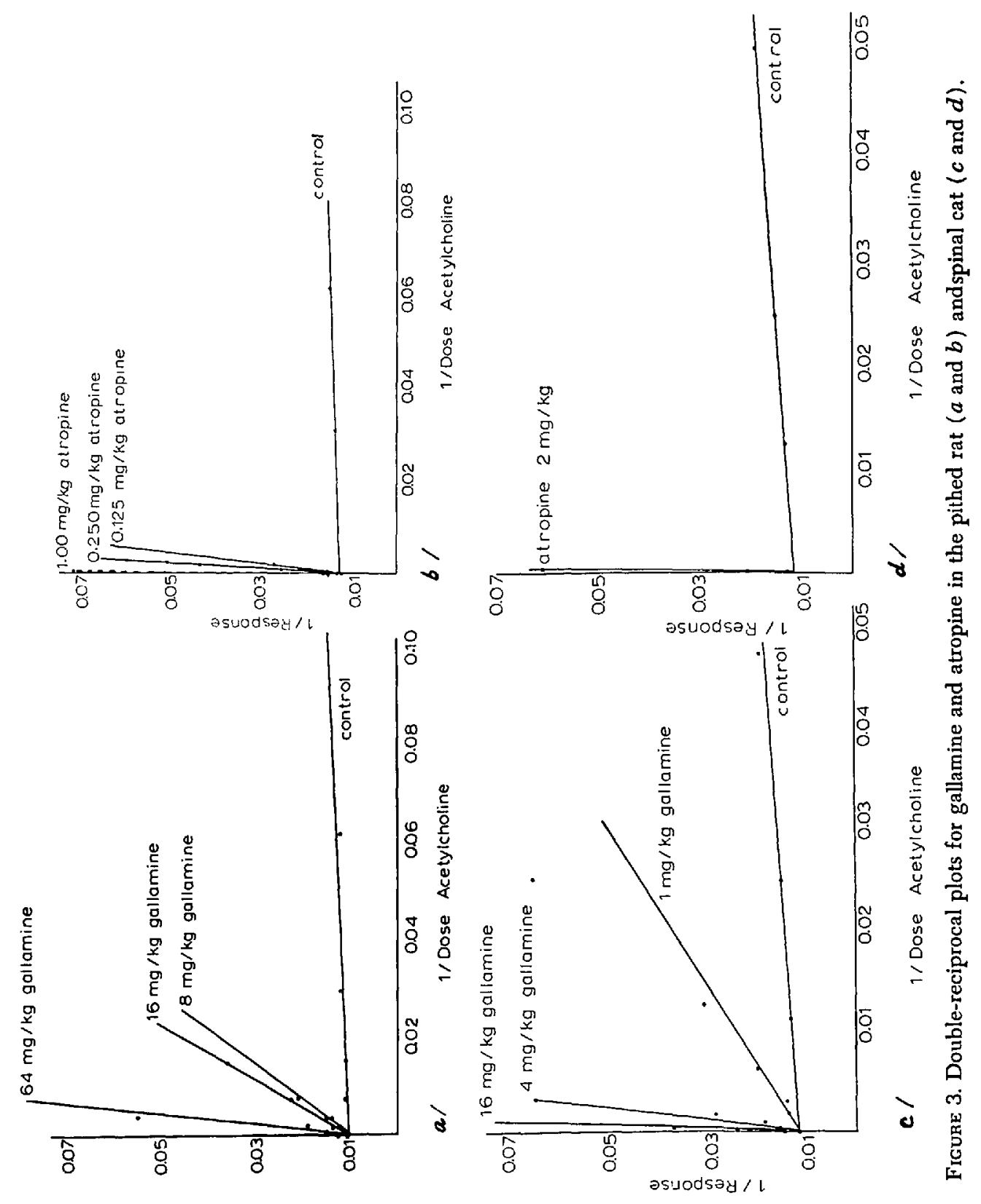




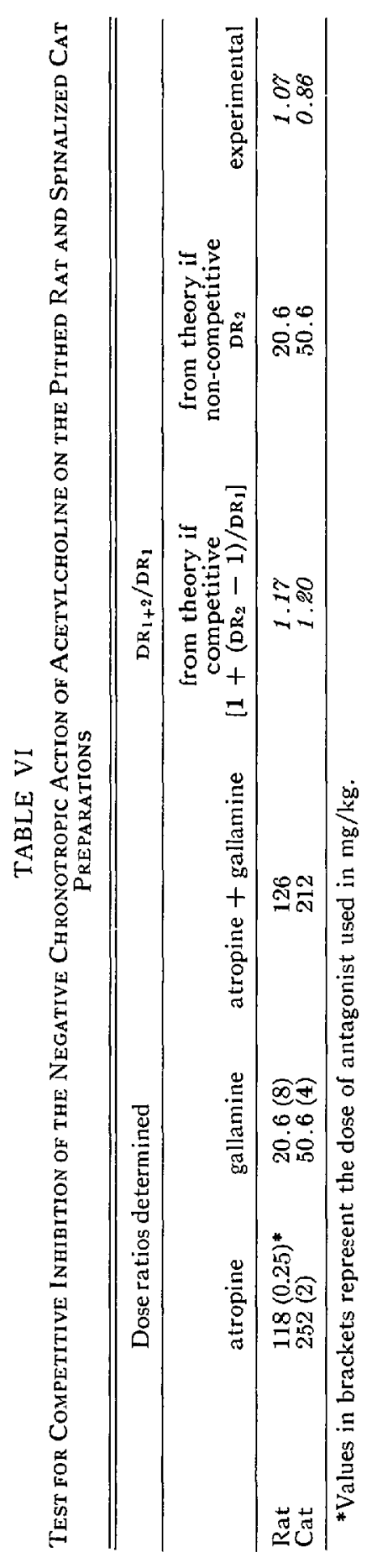


The results of the test described by Abramson et al. ${ }^{24}$ are shown in Table VI. In both species the experimental values of $\mathrm{DR}_{1+2} / \mathrm{DR}_{1}$ were very close to the theoretical value of this ratio that would be obtained if gallamine were competitive in nature, and radically different from the values calculated for non-competitive receptor interaction.

\section{DisCUSSION}

A true antiacetylcholine action of gallamine on the heart of two mammalian species, the rat and cat, has been demonstrated. This observation is in agreement with the conclusions of Jacob and Depierre ${ }^{27}$ and Riker and Wescoe. ${ }^{5}$ This investigation gives more conclusive evidence, however, as the recently discovered sympathomimetic catecholamine releasing effect of gallamine $e^{2,6,7}$ was blocked by the administration of a beta-adrenergic blocking agent, propranolol. The antiacetylcholine action of gallamine in the presence of hexamethonium, moreover, contradicts the suggestion of other investigations that the vagolytic action of gallamine was primarily due to vagal ganglion blockade. ${ }^{28-31}$ The antiacetylcholine action of gallamine fulfilled all the requirements for a competitive anatagonism of acetylcholine in the dose range used in these experiments: gallamine progressively shifted the agonist dose-response curves to the right in a parallel fashion; maximal responses could still be elicited by acetylcholine with gallamine present. Such dose-response behavior is indicative of competitive antagonism. ${ }^{32,33}$

To further investigate the nature of the antagonism, double-reciprocal plots were drawn for both gallamine and atropine in the rat and cat. The resulting lines varied in slope and $x$ intercept but had the same $y$ intercept, a further indication of competition. The fact that the log-dose-response curves were shifted to the right and the lines of the double-reciprocal plots passed through the same $y$ intercept is positive proof that gallamine's antagonism of acetylcholine, as well as atropine's, is competitive. ${ }^{34}$

Further proof of the competitive nature of gallamine was obtained from the test described by Abramson et al. ${ }^{24}$ The calculated dose ratio $\mathrm{DR}_{1+2} / \mathrm{DR}_{1}$ was very close to the theoretical value of the ratio if gallamine were competitive but very different from the value if gallamine were non-competitive.

When pithed rats were pretreated with hexamethonium the dose-response curves in the presence of either gallamine or atropine were shifted to the right. This was expected, as hexamethonium was preventing the acetylcholine, given intravenously, from releasing further acetylcholine from parasympathetic nerve endings as a result of ganglion stimulation. Thus, more acetylcholine was required intravenously to cause the same degree of bradycardia as before.

Hexamethonium did not cause a significant change in the control curve nor in that obtained with $2 \mathrm{mg} / \mathrm{kg}$ of atropine in spinal cat preparations. The significant shift to the left with $16 \mathrm{mg} / \mathrm{kg}$ of gallamine was therefore unexpected. There are a number of possible explanations for this: hexamethonium could be blocking acetylcholine-induced release of catecholamines, which might have been inadequately blocked in the cat by propranolol; such an action would shift the doseresponse curve to the left. One would expect to see a similar effect on the atropine curves if this were the sole explanation, but such an effect was not seen. It 
is possible, however, that gallamine, unlike atropine, is sympathomimetic, perhaps by releasing catecholamines from nerve endings as suggested by Brown and Crout, ${ }^{6}$ or by potentiating already released amines, ${ }^{35}$ or by having an anticholinesterase activity. ${ }^{36,37}$

These results with hexamethonium on the cat are also consistent with the possibility that a component of the vagolytic action af gallamine was due to parasympathetic ganglion blockade, ${ }^{28-31}$ as gallamine was not as effective in the presence of ganglion blocking doses of hexamethonium. The reason for this species difference must therefore await further study, and we can only speculate which species the human patient most resembles. Should the human resemble the cat rather than the rat, one might, however, predict certain possible drug interactions of relevance to clinical practice. Firstly, the concomitant administration of these two agents, hexamethonium and gallamine, in man might result in fewer cases of tachycardia than when gallamine alone is given; less concern, therefore, might centre on the potentially undesirable effects of this tachycardia. The second possibility relates to cholinomimetic agents such as edrophonium and neostigmine, which are often routinely used to reverse the neuromuscular blocking actions of gallamine. The present study indicates that if the cat resembles man, the presence of hexamethonium could increase the cholinergic actions of these agents on the heart, as gallamine is a less potent vagolytic drug in this situation. Thus atropine pretreatment before the anticholinesterase is given is likely as important from a cardiac viewpoint when it is used to reverse gallamine in the presence of hexamethonium as when it is given to reverse d-tubocurarine.

This discrepancy between the rat and cat results might be resolved by repeating the experiments in the presence of larger doses of propranolol, in an attempt to achieve better cardiac beta blockade. Propranolol's known quinidine-like effect could make this impracticable and, in fact, in this laboratory, death ensued in a few cats given $3 \mathrm{mg} / \mathrm{kg}$ propranolol. Perhaps newer beta blocking drugs could be used, e.g. Sotalol (MJ 1999) which is reported to lack quinidine-like activity. ${ }^{38}$

Alternatively, in the cat, hexamethonium may in some way be interfering with gallamine's ability to compete with acetylcholine for receptor sites. As hexamethonium is not by itself blocking acetylcholine, it seems improbable that it is acting at the same receptor site; perhaps, rather, it is interacting with the acetylcholine-gallamine receptor system in a non-competitive way.

Despite the strong evidence that atropine and acetylcholine act on the same receptor in a competitive manner in the heart, some workers have considered the possibility that atropine "allosterically inhibits" acetylcholine by acting at some other site ${ }^{39}$ If this is true for atropine, it may also be true for gallamine, making other types of hexamethonium-gallamine interactions possible at a receptor site different than that for acetylcholine: e.g. hexamethonium could interact competitively with gallamine; it could be acting uncompetitively by interacting with the gallamine-receptor complex; or it could be acting non-competitively by combining with yet a third receptor. Nevertheless, if atropine is in fact antagonizing acetylcholine in a competitive manner, then it is probable from this study that gallamine does the same. 
We have reconfirmed the cardiovascular selectivity of gallamine's atropinic activity as described earlier by Riker and Wescoe, ${ }^{5}$ by determining the affinity of gallamine as compared to atropine for cholinergic guinea pig gut receptors. In addition, qualitative evidence for this selectivity was obtained, for gallamine unlike atropine did not prevent the copious salivation and mucus secretion induced by acetylcholine.

Although the experiments in the cat and the rat were not designed specifically to study blood pressure effects, an antagonism by gallamine of the vasodepressor action of acetylcholine was demonstrated (unpublished results). When apparent affinity constants were determined, they were found to be very close to those obtained for the cardiac action of gallamine and atropine. The apparent affinity constants for gallamine in the rat and cat respectively were $2.88 \times 10^{5}$ and $2.06 \times$ $10^{6}$, and for atropine in the rat and cat, $2.34 \times 10^{8}$ and $2.23 \times 10^{7}$. Such results indicate that the peripheral cardiovascular cholinergic responses to acetylcholinelike agents might also be blocked by gallamine, and that the specificity of gallamine, although cardiovascular, is not simply cardiac.

During this work, in parallel experiments, gallamine was noted to exert a potent and apparently irreversible antagonism of histamine's contractile effect on the guinea pig ileum preparation in vitro (unpublished results). Perhaps the low incidence of histaminic side effects seen clinically is related to this property of gallamine, a factor not considered before.

The ability of the doses of gallamine used in these experiments to block muscle twitches to indirect nerve stimulation on the rat gastrocnemius-sciatic nerve and cat tibialis anterior-anterior tibial nerve preparations was measured: the lowest dose of gallamine used which produced 100 per cent blockade was $16 \mathrm{mg} / \mathrm{kg}$ in the rat and $4 \mathrm{mg} / \mathrm{kg}$ in the cat. It was noted in these experiments that extensive vagal blockade occurred with doses of gallamine that had only a slight neuromuscular blocking effect and that vagolysis lasted longer than neuromuscular block.

\section{Summary}

Gallamine triethiodide causes tachycardia thought to be due to a specific vagolytic action. Recently, Brown and Crout have shown that gallamine may cause increased inotropic and chronotropic activity due to the release of catecholamines from cardiac sympathetic nerves. As a further analysis of the mechanisms, experiments were performed on pithed rats and spinally transected, braindestroyed cats in vivo pretreated with hexamethonium and/or propranolol to determine the nature of the antiacetylcholine action of gallamine on the heart.

A significant antagonism by gallamine of the negative chronotropic action of acetylcholine on the heart of the pithed rat in vivo, pretreated with hexamethonium and/or propranolol, has been demonstrated. Similarly, gallamine was shown to have a significant antiacetylcholine activity on the heart of the spinal cat preparation. The effect of hexamethonium on the cat, however, differed from that on the rat, as in the former it caused a significant decrease in the apparent affinity constant of gallamine. The possible mechanisms whereby this is caused and the clinical implications, should the cat be similar to man in this regard, are discussed. 
This antiacetylcholine activity of gallamine on the heart (negative chronotropic response to acetylcholine) fulfils many of the requirements for competitive antagonism. Parallel results were obtained with atropine except on the hexamethonium-treated cat. Thus, if atropine acts on the acetylcholine receptor in a competitive manner, it is likely that gallamine does also.

Experiments on the isolated guinea pig ileum in vitro have re-demonstrated the remarkable selectivity of the parasympatholytic activity of gallamine with respect to the cardiovascular system and an interesting antihistaminic action which deserves further study.

As the observed anticholinergic actions of gallamine on the heart of both species were obtained with doses necessary for muscle relaxation, it is conceivable that a true atropine-like action may complement any sympathomimetic action of gallamine in producing the tachycardia encountered in clinical practice.

\section{RÉSUMÉ}

On croyait que la triéthiodure de gallamine produisait une tachycardie à cause de son action vagolytique spécifique. Récemment, Brown et Crout ont démontré que la gallamine pouvait produire un effet inotropique et chronotropique accru à cause de la libération de cathécolamines par les nerfs sympathiques cardiaques. En guise d'analyses plus complètes de ces mécanismes, nous avons fait des expériences sur des rats décérébrés et cordotomisés, sur des chats vivants au cerveau détruit et traités au préalable au propranolol et/ou à I'hexaméthonium pour préciser la nature de l'activité antiacétylcholine de la gallamine sur le cour. Les courbes dose-réponse de l'activité chronotropique négative de l'acétylcholine donnée par voie endoveineuse obtenues après la gallamine par voie endoveineuse et/ou l'atropine confirment l'activité "atropine-like" de la gallamine réalisant plusieurs des exigences comme antagoniste compétitif. Les affinités constantes apparentes pour l'atropine et la gallamine sont différentes chez le rat et chez le chat. Des études faites sur l'iléon du cobaye confirment la sélectivité cardiovasculaire de l'action antimuscarinique de la gallamine. L'antagonisme intéressant de la gallamine par l'hexaméthonium sur le cœur du chat est un exemple d'interaction des médicaments que nous avons discutée. Cette activité antiacétylcholine de la gallamine s'ajoute, selon toute vraisemblance, à toute libération de cathécolamines pour produire la tachycardie observée en clinique.

\section{ACKNOWLEDGMENTS}

The authors wish to acknowledge, in addition to the granting bodies, the generous supplies of gallamine triethiodide (Flaxedil) from Mr. A. G. Creed, General Sales Manager, Poulenc Ltd., Montreal, and of propranolol (Inderal) from Dr. R. O. Davies, Director of Clinical Pharmacology, Ayerst Laboratories, Montreal.

The technical assistance of Mr. Colin Paterson and Mrs. Laurie Bogart, and 
photographic work of Mr. Jacobus Klaase are greatly appreciated. We are indebted to Doctors W. E. G. A. Spoerel and L. W. Hersey for suggesting this basic problem to us.

\section{REFERENCES}

1. Huguenard, P. \& BouÉ, A. Un nouvel Ortho-curare français de synthèse, le 3697 RP. Rapport à la Société d'Anesthésie de Paris, Séance de 17 juin (1948).

2. Sмiтh, N. T. \& Whitcher, C. E. Hemodynamic Effects of Gallamine and Tubocurarine Administered during Halothane Anesthesia. J.A.M.A. 199: 704 (1967).

3. Walton, F. A. Flaxedil: A New Curarizing Agent. C.M.A.J. 63: 123 (1950).

4. Condon, H. A. The Clinical Use of Flaxedil Anaesthesia. 6: 92 (1951).

5. Ruker, W. F. \& Wescoe, W. C. The Pharmacology of Flaxedil with Observations on Certain Analogs. Ann, New York Acad. Sc. 54: 373 (1951).

6. Brown, B. R. \& Chout, J. R. Mechanism of the Positive Inotropic Effect of Gallamine on Guinea Pig Heart Muscle. Fed. Proc. 25: 472 (1966).

7. Brown, B. R. \& Crout, J. R. The Sympathomimetic Effect of Gallamine on the Heart. Anesthesiology. 29: 179 (1968).

8. Shipley, R. E. \& Tilden, J. H. A Pithed Rat Preparation Suitable for Assaying Pressor Substances. Proc. Soc. Exper. Biol. Med. 64: 453 (1947).

9. Burn, J. H. In Practical Pharmacology (Oxford: Blackwell, 1952), p. 35.

10. Litchfield, J. T. \& Wrlcoxon, F. A Simplified Method of Evaluating Dose-effect Experiments. J. Pharmacol. Exper. Therap. 96: 99 (1949).

11. Gaddum, J. H. The Quantitative Effects of Antagonistic Drugs. J. Physiol. (London). 89: 70 (1937).

12. Ferguson, F, C. Effects of 4- amino-N 10 -methyl-pteroylglutamic Acid on the Extracellular Fluids of Rats. Proc. Soc. Exper. Biol. Med. 77: 259 (1951).

13. Lolli, G.; Rubin, M.; \& Greenberg, L. A. The Effect of Ethyl Alcohol on the Volume of Extracellular Water. Quart. J. Stud. Alcohol. 5: 1 (1944).

14. Scheer, B. T.; Straub, E.; Fields, M.; Meserve, E. R.; Hendrick, C.; \& Deuel, H. J. The Effect of Fat Level on the Diet on General Nutrition. J. Nutr. 34: 581 (1947).

15. Lands, A. M.; Cutring, R. A.; \& Larson, P. S. The Size of the Extracellular Fluid Compartment before and after Massive Infusions. Am. J. Physiol. 130: 421 (1940).

16. Hatai, S. Changes in the Composition of the Entire Body of the Albino Rat during the Life Span. Am. J. Anat. 21: 23 (1917).

17. Moultow, C. R. Age and Chemical Development in Mammals. J. Biol. Chem. 57; 79 (1923).

18. Skelton, H. The Storage of Water by Various Tissues of the Body. Arch. Intern. Med. (Chicago). 40: 140 (1927).

19. Magnus, $R$. Versuche am überlebenden Dünndarm von Säugetiern. Pllueger Arch. Ges. Physiol. 102: 123 (1904).

20. Rang, H. P. Stimulant Actions of Volatile Anaesthetics on Smooth Muscle. Brit. J. Pharmacol. 22: 356 (1964).

21. PAton, W. D. M. \& VIZI, E. S. The Inhibitory Action of Noradrenaline and Adrenaline on Acetylcholine Output by Guinea-pig Ileum Longitudinal Muscle Strip. Brit. J. Pharmacol. 35: 10 (1969).

22. Webs, J. L. In Enzyme and Metabolic Inhibitors (New York: Academic Press, 1963), vol. I, p. 150.

23. Dowd, J. E. \& Riggs, D. S. A Comparison of Estimates of Michaelis-Menten Kinetic Constants from Various Linear Transformations. J. Biol. Chem. 240: 863 (1965).

24. Amramson, F. B.; Barlow, R. B.; Mustafa, M. G.; \& Stephenson, R. P. Relationships between Chemical Structure and Affinity for Acetylcholine Receptors. Brit. J. Pharmacol. 37: 207 (1969).

25. Ariëns, E. J.; Simonis, A. M.; \& Van Rossum, J. M. Drug-Receptor Interaction: Interaction of One or More Drugs with Different Receptor Systems. Molecular Pharmacology. 1, 366, section IIB (New York and London: Academic Press, 1964)

26. Paton, W. D. M. \& Rang, H. P. The Uptake of Atropine and Related Drugs by Intestinal Smooth Muscle of Guinea Pig in Relation to Acetylcholine Receptors. Proc. R. Soc. B. 163: 1 (1965).

27. JАСОВ, J. \& DEPIERRE, F. Recherches sur l'action ganglionnaire paralysante des curari- 
sants de la serie des éthers phénoliques de la triéthylcholine. Arch. internat. pharmacodyn. 83: 1 (1950).

28. Bovet, D.; Depierre, F.; Courvoisier, S.; \& de Lestrance, Y. Recherches sur les poisons curarisants de synthèse. Arch. internat. pharmacodyn. 80: 172 (1949).

29. Bovet, D.; Depierre, F.; \& DE Lestrange, Y. Propriétés curarisantes des éthers phénoliques à fonctions ammonium quaternaires. Compt. rend. Acad. sc. (Paris). 225: 74 (1947).

30. Delia Bella, D.; Rognoni, F.; \& Teotino, U. M. Curare-like Drugs and Vagal Synapses: Comparative Study in vitro on the Isolated Vagus-stomach Preparation of the Rat. J. Pharm. Pharmacol. 14: 701 (1962).

31. Desmarez, J. J. Effets comparatifs de la d-tubocurarine et du Flaxedil sur le système sympathique. Compt. rend. Soc. biol. (Paris). 148: 722 (1954).

32. Aniëns, E. J.; Smonis, A. M.; \& De Groot, W. M. Affinity and Intrinsic Activity in the Theory of Competitive and Noncompetitive Inhibition and an Analysis of Some Forms of Dualism in Action. Arch. internat. pharmacodyn. 100: 298 (1954).

33. Arunlakshana, O. \& Schind, H. O. Some Quantitative Uses of Drug Antagonists. Brit. J. Pharmacol. 14: 48 (1959).

34. Matsumoto, H. \& Kumor, T. "Dose-action Curves" of Various Pharmacological Agents and a Mathematical Analysis of Mechanism of Antagonism. Kobe J. Med. Sc. 4: 139 (1958).

35. Melville, K. I. On the Mechanism of the Cardiovascular Actions of Digitalis: Observations on the Influence of Flaxedil, Atropine or Vagotomy. J. Pharmacol. Exper. Therap. 106: 208 (1952).

36. Changeux, J. P. Responses of Acetylcholinesterase from Torpedo Marmorata to Salts and Curarizing Drugs. Molec. Pharmacol. 2: 369 (1966).

37. Fordes, F. F. The Fate of Muscle Relaxants in Man. Acta anaesth. scandinav, 1: 63 (1957).

38. Fitzgerald, J. D. Perspectives in Adrenergic Beta-receptor Blockade. Clin. Pharmacol. Therap. 10: 292 (1969).

39. Monod, J.; Changeux, J. P.; \& Jacon, F. Allosteric Proteins and Cellular Control Systems. J. Molec. Biol, 6: 306 (1963). 